\title{
PENILAIAN KEBUTUHAN PELATIHAN PADA TINGKAT INDIVIDU PETUGAS REKAM MEDIS
}

\author{
TRAINING NEED ASSESMENT AT INDIVIDUAL TASK OF MEDICAL RECORD STAFF \\ Helda Budiyanti, Nyoman Anita Damayanti \\ Fakultas Kesehatan Masyarakat, Universitas Airlangga, Surabaya \\ E-mail: heldabudiyanti@gmail.com
}

\begin{abstract}
The increased number of complaint patient indicated performance gap of medical records officer. Training needs assessment was a systematically order of process to discover and identified the existence of a disparity performance caused by a lack of knowledge, attitude and skills in doing the work. Individual analysis identified a disparity between requirements of work to requirement an organization that owned by their respective employee. The purpose of this study was to develop a training needs medical records staff at Undaan Surabaya Eye Hospital, based on the training needs assessment through individual analysis. This was a descriptive study, subject of research were medical record officers who works in Undaan Surabaya Eye Hospital. More that 56,00\% was included in good category knowledge. The most medical records officers has $88 \%$ excellent working attitude, skilled officers medical records in conducted technical work related duties $77.78 \%$ good category, and softkills as a whole into the category of a good $49,5 \%$. This study concluded be taken from this study was the training needs of medical record staff in Undaan Eye Hospital Surabaya generally was training on knowledge and skill of management medical records.
\end{abstract}

Keywords :individual analysis, medical record staff, training need assessment

\section{PENDAHULUAN}

Sumber daya manusia yang kompeten dan berkualitas sangat dibutuhkan untuk mendukung produktivitas dan aktivitas agar tujuan suatu organisasi dapat tercapai dengansempurna. Keberhasilan organisasi sangat ditentukan oleh kualitas sumber daya manusia yang bekerja di dalamnya (Setyowati, 2007).

Rumah Sakit Mata Undaan Surabaya merupakan salah satu Rumah Sakit swasta yang khusus menangani penyakit mata. Dalam memberikan pelayanan yang tepat pada penderita penyakit mata, setiap petugas dituntut dapat mengaplikasikan ilmunya dengan baik dan tepat guna. Disisi lain Rumah Sakit perlu memiliki kelebihan yang dapat diunggulkan terutama dalam hal skill petugas. Sayangnya pada 3 tahun terakhir berturut-turut Rumah Sakit mendapatkan komplain terkait pelayanan pada pasien.

Berdasarkan data komplain Rumah Sakit

Mata Undaan Surabaya, jumlah komplain pasien pada tahun 2013 mengalami peningkatan dari tahun sebelumnya. Pada tahun 2011 terdapat 15 komplain, tahun 2012 sebanyak 13 komplain, dan 2013 sebesar 59 komplain dari pasien terhadap pelayanan yang diberikan. Kenaikan komplain pasien tersebut mengindikasikan bahwa pelayanan yang diberikan oleh petugas kurang baik. Isi komplain terbanyak mengenai sikap dan keramahan petugas, sedangkan unit kerja tertinggi yang mendapatkan komplain adalah unit rekam medis. Adanya suatu complain dari pasien merupakan suatu indikator untuk dilakukannya penilaian kebutuhan pelatihan pada karyawan. 
Salah satu mekanisme yang bisa ditempuh dalam mewujudkan SDM yang profesional adalah melalui pembelajaran dan pengembangan sumber daya manusia (Budiyanti, 2015). Pembelajaran dan pengembangan sumber daya manusia dapat dilaksanakan dengan pendidikan dan pelatihan, on/off job training, pemberian sistem reward, and punishment, serta pengembangan tim yang efektif. Hasil dari pembelajaran dan pengembangan akan membuat karyawan puas terhadap pekerjaannya, sehingga dapat membangun komitmen dan etos kerja yang tinggi, yang pada akhirnya mampu meningkatkan karyawan (Supriyanto \& Wulandari, 2010).

Secara keseluruhan unit kerja di Rumah Sakit Mata Undaan Surabaya pada tahun 2014 tidak melakukan penilaian kebutuhan pelatihan pada karyawan. Penelitian ini bertujuan untuk menyusun kebutuhan pelatihan petugas rekam medis di Rumah Sakit Mata Undaan Surabaya. Hasil penelitian diharapkan dapat menjadi suatu masukan bagi Rumah Sakit untuk meningkatkan kualitas sumber daya manusia.

\section{PUSTAKA}

Menurut Veithzal Rifai (2004) mendefinisikan kebutuhan pelatihan adalah untuk memenuhi kekurangan pengetahuan, meningkatkan keterampilan atau sikap dengan masing-masing kadar yang bervariasi. Penilaian kebutuhan pelatihan biasanya terdiri atas tiga jenis yang bisa dijadikan sebagai alat untuk menilai kebutuhan pelatihan, yakni analisis organisasi, analisis pekerjaan dan analisis individu (Blanchard \& Thacker, 1999).

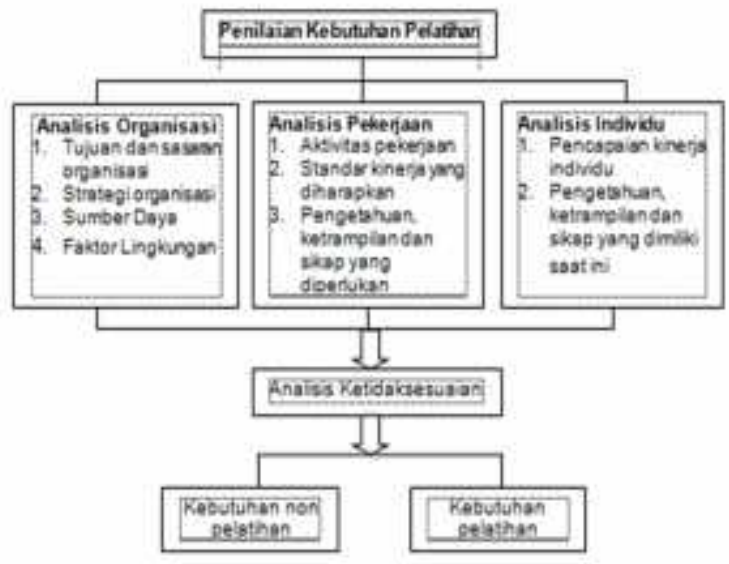

Gambar 1Penilaian Kebutuhan Pelatihan Sumber: Blanchard \& Thacker (1999).

Menurut Blanchard dan Thacker (1999) setelah tugas dan persyaratan KSA (knowledge, skill, attitude) sudah ditetapkan pada analisis pekerjaan, penilaian kebutuhan harus menentukan siapa yang belum sesuai mencapai target yang diharapkan. Ketidaksesuaian kinerja adalah perbedaan yang terjadi antara perilaku yang diharapkan dengan perilaku aktual.

Analisis individu diperlukan untuk mengetahui bagaimana kinerja setiap karyawan ketika melakukan pekerjaan. Perbedaan antara kinerja yang diinginkan dengan sesungguhnya merupakan kebutuhan pelatihan bagi individu. Kinerja standar yang telah ditetapkan pada tingkat operasi merupakan kinerja yang ingin dicapai. Sedangkan informasi mengenai kinerja aktual karyawan dapat diperoleh dari data kinerja individu, penilaian supervisor, attitude survey, wawancara, dan sebagainya. Kesenjangan antara kinerja aktual dan 
kinerja yang ingin dicapai akan diisi dengan pelatihan (Wulandari, 2005).

Pada dasarnya kebutuhan itu adalah untuk memenuhi kekurangan pengetahuan, meningkatkan keterampilan atau sikap sesuai porsinya. Hasil dari penilaian kebutuhan pelatihan adalah kebutuhan pelatihan dan kebutuhan non pelatihan. Dibutuhkan pelatihan apabila terjadi kesenjangan KSA (Knowledge, Skill, Attitude), dan langkah selanjutnya adalah membuat daftar KSA yang jelas untuk dikembangkan pada pelatihan. Ketidaksesuaian kinerja yang bukan dikarenakan kesenjangan KSA maka solusi untuk masalah tersebut bukanlah pelatihan. Kemungkinan penyebab ketidaksesuaian kinerja adalah sistem reward and punishment yang belum sesuai, kurangnya feedback, serta hambatan dalam sistem(Tamba, 2009).

Pelatihan dikatakan berhasil jika dapat merespon kebutuhan atau masalah tertentu suatu organisasi. Penilaian kebutuhan pelatihan digunakan oleh departemen sumber daya manusia ataupun departemen pelatihan dan pengembangan untuk mengidentifikasi kebutuhan pelatihan organisasi maupun individu. Dengan melakukan penilaian kebutuhan, penentuan pelatihan yang salah merupakan penyebab kegagalan pelatihan akan segera dapat diantisipasi sebelumnya. Dengan mengidentifikasi kebutuhan, baik masalah-masalah aktual maupun potensial, organisasi dapat menghemat biaya dan waktu dalam usaha pengembangan sumber daya manusia organisasi. Tentu saja, untuk menghasilkan pelatihan yang efektif, para profesional pelatihan perlu menekankan doing the right things the first time(Wulandari, 2005).

\section{METODE}

Penelitian ini merupakan studi kasus di Rumah Sakit Mata Undaan Surabaya. Jenis penelitian yang digunakan adalah deskriptif melalui pendekatan cross sectional. Populasi dalam penelitian ini seluruh petugas yang bekerja di unit Rekam Medis Rumah Sakit Mata Undaan Surabaya. Sumber informasi yaitu berasal dari seluruh petugas rekam medis yang menjadi responden sebanyak 18 orang sebagai unit analisis. Penelitian ini dilakukan selama Mei hingga Juni 2015.

Data primer yang dikumpulkan melalui pengisian kuesioner yang diajukan pada petugas untuk mengidentifikasi pengetahuan dan sikap kerja, sedangkan penilaian ketrampilan didapatkan melalui pengisian kuesioner oleh kepala unit. Informasi yang diperoleh kemudian disusun kebutuhan pelatihan untuk petugas rekam medis di Rumah Sakit Mata Undaan Surabaya. Petugas disebut membutuhkan pelatihan jika hasil penilaian pengetahuan, sikap kerja, dan ketrampilan masuk dalam kategori sangat kurang, kurang, baik, dan sangat baik $\leq 80 \%$. Apabila hasil penilaian termasuk dalam kategori sangat baik $\geq 80 \%$ maka petugas tidak membutuhkan pelatihan.

\section{HASIL DAN PEMBAHASAN}

Mayoritas petugasyang menjadi responden merupakan usia tua yaitu $\geq 31$ tahun. Dalam 
menjalankan peran dan fungsinya sebagai petugas, umur tidak dapat dijadikan patokan untuk menilai kinerja, terdapat unsur kemampuan yang luas antara lain yang menyangkut aspek pengetahuan, sikap dan ketrampilan(Hananto \& S., 2013).

Jenis kelamin terbanyak adalah pria sebesar $55,56 \%$ dan yang berjenis kelamin wanita sebesar 44,44\%. Kemungkinan hal ini terjadi karena pengelolaan rekam medis berkaitan juga dengan teknologi dan sistem komputer sehingga minat kerja pada rekam medis kebanyakan pria(Budiyanti, 2015).Petugas rekam medis memiliki masa kerja lebih dari 5 tahun sebesar $77,78 \%$. Dengan masa kerja petugas yang lama maka pengalaman kerja petugas juga semakin banyak dalam melakukan pengelolaan rekam medis. Masa kerja yang lama dapat didorong oleh faktor individu dan lingkungan tempat mereka bekerja.Mayoritas pendidikan terakhir yang ditempuh oleh petugas rekam medis kebanyakan adalah SMA/SMK sebesar $77,78 \%$.

Pada penelitian ini, akan diidentifikasi pengetahuan, sikap kerja, dan ketrampilan yang dimiliki petugas rekam medis. Kesenjangan antara yang dimiliki dengan yang dibutuhkan petugas merupakan fokus analisis penilaian kebutuhan pelatihan individu. Hasil dari kesenjangan nantinya akan dijadikan sebagai kebutuhan pelatihan masingmasing individu petugas rekam medis.

\section{Analisis Pengetahuan Petugas Rekam Medis}

Analisis individu berupa pengetahuan petugas rekam medis meliputi pengetahuan tentang pengelolaan rekam medis secara umum. Pengetahuan ini meliputi Alur Rekam Medis, Pengolahan Rekam Medis (assembling, coding, indexing, analysing, dan filling), sistem identifikasi berkas, tanggungjawab bagian kerja rekam medis, tata cara penulisan rekam medis, penyimpanan dan pengembalian berkas.Gambaran distribusi jenis pengetahuan petugas rekam medis dapat dilihat pada Tabel 1.

Tingkat pengetahuan petugas tentang pengelolaan rekam medis secara umum termasuk dalam kategori kurang karena belum memenuhi standar yaitu $\geq 80 \%$ sangat baik. Pengetahuan yang kurang dapat disebabkan oleh berbagai faktor, misalnya pendidikan, usia, ekonomi, budaya dan lainnya. Hal ini juga berkaitan dengan pendidikan terakhir yang dimiliki petugas rekam medis yang masih rendah.

Pengetahuan adalah informasi yang telah diproses dan diorganisasikan untuk memperoleh pemahaman, pembelajaran, dan pengalaman yang terakumulasi sehingga bisa diaplikasikan ke dalam masalah atau proses tertentu. Semua pekerjaan memerlukan beberapa jenis pengetahuan, mencakup pengetahuan umum maupun pengetahuan tentang prosedur kerja. Analisis pekerjaan harus membuat list tugas yang pada saat dianalisis akan merujuk pada syarat pengetahuan yang penting agar dapat berhasil menunaikan pekerjaan/jabatan tersebut (Blanchard \& Thacker, 1999). Dalam hal ini petugas dituntut untuk memahami pengetahuan umum terkait rekam medis. 
Dari hasil pengukuran tingkat pengetahuan petugas rekam medis, petugas belum memahami pengelolaan rekam medis secara umum. Hal ini menunjukkan bahwa seluruh petugas rekam medis yang tingkat pengetahuannya pada kategori sangat baik kurang dari $80 \%$, baik, kurang, dan sangat kurang dapat ditingkatkan menjadi sangat baik melalui pelatihan.

Hasil persentase jenis pengetahuan yang masih dirasa kurang oleh petugas adalah pada semua indikator pengetahuan. Hal ini dikarenakan tidak ada seorang pun yang masuk dalam kategori sangat baik. Pengetahuan petugas mengenai rekam medis secara teoritis tidak terlalu spesifik didapatkan dalam masa pendidikan, maka untuk itu pihak manajemen perlu merencanakan pelatihan pengetahuan agar dapat meningkatkan pengetahuan petugas tentang pengelolaan rekam medis. Apabila kesenjangan pengetahuan ini tidak segera diatasi dengan baik, maka akan menyebabkan penurunan produktivitas petugas dan terjadi peningkatan komplain oleh pasien, dan berdampak buruk bagi Rumah Sakit.

Pengetahuan rekam medis secara umum ini harus dimiliki petugas, kemudian diikuti dengan sikap positif dan dipraktekkan dalam tindakan. Antara pengetahuan, sikap dan perilaku selayaknya berjalan secara sinergis karena terbentuknya perilaku baru, akan dimulai dari pengetahuan, yang selanjutnya akan menimbulkan respon batin dalam bentuk sikap dan dibuktikan dengan adanya tindakan atau praktek. Namun pengetahuan dan sikap tidak selalu akan diikuti oleh adanya tindakan atau perilaku (Notoadmojo, 2003).

\section{Analisis Sikap Kerja Petugas Rekam Medis}

Analisisindividu menilai kecenderungan
petugas dalam merespon suatu pernyataan yang
berhubungan dengan sikap kerja. Gambaran petugas mengenai sikap kerja dapat dipelajari pada tabel 1 dbawah.

Sikap kerja petugas rekam medis sebesar $88 \%$ menunjukkan kategori sangat baik, dan $12 \%$ termasuk dalam kategori baik. Hal ini menunjukkan respon positif dari petugas rekam medis dalam melakukan pekerjaannya. Sikap kerja yang positif ini dapat dipengaruhi oleh faktor internal dan eksternal yang berasal dari masing-masing petugas. Seperti motivasi, emosional dan lingkungan Rumah Sakit.

Sikap (attitude) sebagai pernyataan evaluatif, baik yang menyenangkan maupun tidak menyenangkan terhadap objek, individu, atau peristiwa. Hal ini mencerminkan bagaimana perasaan seseorang tentang sesuatu. Sikap kerja merupakan sikap seseorang terhadap pekerjaannya yang mencerminkan pengalaman pribadi baik itu menyenangkan atau tidak dalam bekerja serta harapan terhadap masa yang akan datang (Robbins, 2007).

Sikap kerja dapat dijadikan indikator keberhasilan dalam sebuah pekerjaan. Faktor internal berasal dari dalam diri petugas meliputi motivasi, emosional, psikologis terhadap pekerjaan, kedekatan dengan rekan kerja, dan kenyamanan yang tercipta 
dari diri sendiri. Faktor eksternal berasal dari lingkungan pekerjaan juga sangat berperan dalam pembentukan sikap seseorang, meliputi kondisi pekerjaan, hubungan kerja, rasa aman, lingkungan kerja, dan fasilitas dalam bekerja. Semakin tinggi tingkat kenyamanan seseorang saat bekerja maka semakin tinggi pula sikap kerja yang dihasilkan.

Berdasarkan hasil sikap kerja yang termasuk dalam kategori sangat baik, maka pelatihan yang berhubungan dengan sikap kerja petugas belum merupakan prioritas untuk saat ini, namun apabila dikemudian hari ditemukan ada banyak keluhan baik itu dari klien eksternal atau klien internal mengenai sikap petugas, maka tidak menutup kemungkinan pelatihan tentang sikap kerja dibutuhkan.

\section{Analisis Ketrampilan Petugas}

Penilaian yang diukur meliputi ketrampilan petugas yaitu pekerjaan teknis dan non teknis dalam melaksanakan tugasnya. Hasil penilaian menginformasikan bahwa ketrampilan teknis petugas rekam medis termasuk dalam kategori kurang karena masih belum memenuhi standar yaitu lebih dari $80 \%$ sangat baik.

Hasil penilaian ketrampilan, jenis ketrampilan teknis yang masih menjadi masalah adalah mengenai tugas rekam medis lain yang diberikan dan kepatuhan petugas sesuai SOP. Kedua indikator ini menjadi isu dan membutuhkan pelatihan, dikarenakan persentase masalah lebih dari $20 \%$. Hal ini disebabkan karena sistem yang diterapkan di RS tidak sesuai dengan uraian tugas dan kemampuan masing-masing individu petugas.

RS Mata Undaan telah membagi uraian tugas untuk petugas rekam medisnya berdasarkan bagian kerja pada pengelolaan rekam medis. Pada kenyataannya terdapat beberapa pekerjaan yang seharusnya dilakukan petugas bagian kerja tetapi dilakukan juga oleh petugas rekam medis lainnya. Tugas pokok petugas berkaitan dengan uraian tugasnya, sedangkan tugas tambahan yaitu melakukan kegitatan rekam medis lainnya. Kondisi ini yang dapat menyebabkan ketrampilan petugas menjadi kurang terampil dalam melakukan pekerjaan karena diluar kemampuan dan tanggung jawabnya.

Ketrampilan adalah kecakapan dalam
melakukan sesuatu, bukan sekedar mengetahui
tentang hal tersebut.Selain ketrampilan teknis, softskill petugas jugadituntut terampil dalam melakukan pekerjaan.

Ketrampilan non teknis hasil penilaian petugas juga belum memenuhi standar yaitu lebih dari $80 \%$ sangat baik, sehingga masih terdapat beberapa jenis ketrampilan non teknis yang dirasa kurang dan perlu untuk ditingkatkan.Jenis ketrampilan non teknis yang menjadi masalah yaitu kedisiplinan, keramahan, dan komunikasi efektif, dapat dilihat pada tabel 1. Ketiganya mendapatkan persentase yang tinggi melebihi dari $20 \%$.

Softskillpetugas dalam melkukan pekerjaan rekam medis bisa disebabkan oleh faktor masingmasing individu petugas, misalnya dalam hal menjaga 
etika, berkomunikasi, kerjasama, kedisiplinan, dan lainnya. Ketrampilan non teknis ini sebenarnya dapat dibentuk di lingkungan Rumah Sakit dengan cara mengikuti pelatihan atau menerapkan sistem reward and punishment. Karena softskill ini sangat diperlukan petugas untuk menunjang ketrampilan mereka.

Dapat disimpulkan bahwa terdapat sebagian petugas rekam medis yang masih termasuk dalam kategori kurang dalam menjalankan tugasnya, baik dalam ketrampilan teknis maupun non teknis. Pihak manajemen perlu meningkatkan lagi ketrampilan petugas melalui perencanaan pelatihan dengan baik. Pelatihan yang diberikan disesuaikan dengan ketrampilan yang dirasakan kurang dalam melakukan pekerjaan pada unit kerja rekam medis.

Tabel 1

Jenis Pengetahuan, Sikap dan Ketrampilan Petugas Rekam Medis RS Mata Undaan Surabaya Tahun 2015

\begin{tabular}{|c|c|c|c|c|c|c|}
\hline \multirow{2}{*}{ Jenis Pengetahuan } & \multicolumn{2}{|c|}{ Kurang } & \multicolumn{2}{|c|}{ Baik } & \multicolumn{2}{|c|}{ Jumlah } \\
\hline & $\mathbf{n}$ & $\%$ & $\mathbf{n}$ & $\%$ & $\mathbf{n}$ & $\%$ \\
\hline Proses pengolahan RM & 8 & 44,5 & 10 & 55,5 & 18 & 100 \\
\hline Penulisan berkas RM & 6 & 33,4 & 12 & 66,6 & 18 & 100 \\
\hline Sistem penyimpanan RM & 6 & 33,4 & 12 & 66,6 & 18 & 100 \\
\hline Sistem pengembalian RM & 6 & 33,4 & 12 & 66,6 & 18 & 100 \\
\hline Sistem identifikasi berkas RM & 5 & 27,8 & 13 & 72,2 & 18 & 100 \\
\hline Tugas Setiap bagian RM & 7 & 38,9 & 11 & 61,1 & 18 & 100 \\
\hline Alur RM & 10 & 55,5 & 8 & 44,5 & 18 & 100 \\
\hline \multicolumn{7}{|l|}{ Jenis Sikap Kerja } \\
\hline Keramahan & 1 & 5,5 & 17 & 94,5 & 18 & 100 \\
\hline Empati & 3 & 16,7 & 15 & 83,3 & 18 & 100 \\
\hline Disiplin & 2 & 11,2 & 16 & 88,8 & 18 & 100 \\
\hline Kerjasama & 2 & 11,2 & 16 & 88,8 & 18 & 100 \\
\hline Ketelitian & 3 & 16,7 & 15 & 83,3 & 18 & 100 \\
\hline Etos Kerja & 3 & 16,7 & 15 & 83,3 & 18 & 100 \\
\hline Emosional & 6 & 33,4 & 12 & 66,6 & 18 & 100 \\
\hline \multicolumn{7}{|l|}{ Jenis Ketrampilan Teknis } \\
\hline Tugas rekam medis lain & 9 & 50 & 9 & 50 & 18 & 100 \\
\hline Kepatuhan sesuai SOP & 6 & 33,4 & 12 & 66,6 & 18 & 100 \\
\hline Pemeriksaan Kelengkapan Berkas & 3 & 16,7 & 15 & 83,3 & 18 & 100 \\
\hline Pelaporan & 2 & 11,2 & 16 & 88,8 & 18 & 100 \\
\hline Pemeriksaan identitas pasien & 2 & 11,2 & 16 & 88,8 & 18 & 100 \\
\hline Pembuatan Nomor Pasien & 2 & 11,2 & 16 & 88,8 & 18 & 100 \\
\hline \multicolumn{7}{|l|}{ Jenis Ketrampilan Non Teknis } \\
\hline Keramahan & 8 & 44,5 & 10 & 10 & 18 & 100 \\
\hline Kedisiplinan & 13 & 72,3 & 5 & 5 & 18 & 100 \\
\hline Komunikasi Efektif & 6 & 33,4 & 12 & 12 & 18 & 100 \\
\hline Koordinasi & 2 & 11,2 & 16 & 88,8 & 18 & 100 \\
\hline Empati & 1 & 5,5 & 17 & 94,5 & 18 & 100 \\
\hline
\end{tabular}


Pada pengukuran pengetahuan, sikap kerja, dan ketrampilan diidentifikasi pada bagian mana petugas rekam medis mendapatkan penilaian kurang, maka hal tersebut dianggap butuh pelatihan. Setiap penilaian pengetahuan, sikap kerja, dan ketrampilan ditelusuri kembali item yang hasilnya kurang untuk mendapatkan perhatian.

Berdasarkan pengukuran kebutuhan pelatihan, dapat diidentifikasi hasil penilaian kebutuhan pelatihan pada petugas rekam medis di Rumah sakit Mata Undaan Surabaya dari segi pengetahuan, sikap kerja, dan ketrampilan. Terdapat Petugas Rekam Medis yang memiliki kesenjangan dari sisi pengetahuan saja, ketrampilan saja, atau kombinasi dari keduanya. Hasil sikap kerja belum menunjukkan kesenjangan (attitude) pada petugas rekam medis.

Analisis kebutuhan pelatihan adalah suatu proses kegiatan yang bertujuan untuk menemukan dan mengenali adanya suatu kesenjangan pengetahuan, ketrampilan dan sikap yang dapat ditingkatkan melalui pelatihan (Lutfi, 2008).

Kesenjangan antara pengetahuan, ketrampilan dan sikap yang diperlukan oleh pekerjaan dengan pengetahuan, ketrampilan sikap yang telah dimiliki inilah yang merupakan arti kebutuhan akan training. Tugas dan tanggung jawab kerja serta pengetahuan, ketrampilan dan sikap dalam melakukan pekerjaan merupakan fokus analisis individu (Simamora, 2006).

Penentuan kebutuhan pelatihan bagi petugas rekam medis di Rumah Sakit Mata Undaan Surabaya belum berdasarkan training needs assessment.
Apabila setiap individu petugas rekam medis dilakukan penilaian kebutuhan pelatihan maka diharapkan setiap petugas rekam medis baik yang sudah lama bekerja maupun yang baru bekerja di Rumah Sakit Mata Undaan dapat terpenuhi dari segi pengetahuan, sikap, maupun ketrampilan mengenai bidang pekerjaan dan prosedur kerja yang dilakukan.

Hasil penilaian yang diperoleh melalui training needs assessment pada petugas rekam medis, antara lain kebutuhan pelatihan pengetahuan, ketrampilan teknis, dan softskill.Kebutuhan pelatihan pengetahuan petugas meliputisistem identifikasi berkas, alur rekam medis, penulisan rekam medis, sistem pengembalian, sistem penyimpanan, tugas dan tanggung jawab tiap bagian kerja. Pelatihan pengetahuan ini ditujukan pada seluruh petugas rekam medis sebanyak 18 orang.

Sebanyak 9 orang petugas membutuhkan pelatihan ketrampilan teknis terkaitkegiatan rekam medis lainnya, dan 6 petugas memerlukan pelatihan mengenai kepatuhan sesuai SOP. Pelatihan softskilkeramahan pada 8 petugas, 6 petugas memerlukan pelatihan komunikasi efektif, dan 13 orang membutuhkan pelatihan kedisiplinan.

Secara keseluruhan petugas membutuhkan pelatihan pengelolaan rekam medis terutama dalam hal pengetahuan rekam medis secara umum. Pengetahuan inilah yang nantinya akan mendorong sikap dan ketrampilan kerja petugas rekam medis dapat menjadi lebih baik lagi. Hasil dari kebutuhan pelatihan ini nantinya dapat diteruskan sebagai 
perencanaan pelatihan petugas rekam medis Rumah Sakit Mata Undaan Surabaya.

\section{SIMPULAN}

Tingkat pengetahuan petugas mengenai pengelolaan rekam medis secara umum termasuk dalam kategori kurang. Sikap Kerja yang ditunjukkan petugas rekam medis dalam melakukan pekerjaannya berada pada kategori sangat baik. Ketrampilan petugas rekam medis di Rumah Sakit Mata Undaan Surabaya dalam melakukan pekerjaan teknis maupun non teknis masuk dalam kategori kurang dan membutuhkan pelatihan karena belum memenuhi indikator $\geq 80 \%$ sangat baik.

Kebutuhan pelatihan petugas rekam medis di Rumah Sakit Mata Undaan Surabaya meliputi pelatihan pengetahuan mengenai sistem identifikasi berkas, alur rekam medis, penulisan rekam medis, sistem pengembalian, sistem penyimpanan, tugas dan tanggung jawab tiap bagian kerja. Pelatihan ketrampilan teknis meliputi kegiatan rekam medis lainnya dan kepatuhan petugas sesuai SOP, serta pelatihan softskill terkait keramahan, komunikasi efektif, dan kedisiplinan.

Penelitian ini hanya terbatas pada pengkajian masalah berdasarkan analisis individu penilaian kebutuhan pelatihan petugas rekam medis, dan terbukti terdapat kesenjangan antara pengetahuan, serta ketrampilan petugas dalam melakukan pekerjaannya. Rumah Sakit perlu menganalisis lebih mendalam terkait perencanaan kebutuhan pelatihan pada petugas rekam medis. Untuk peneliti selanjutnya dapat dilakukan penilaian kebutuhan pelatihan berdasarkan analisis pekerjaan dan organisasi. Sehingga dapat diketahui penyebab utama dari adanya peningkatan jumlah komplain pasien di Rumah Sakit Mata Undaan Surabaya.

\section{DAFTAR PUSTAKA}

Blanchard, N., \& Thacker, J. (1999). Effective Training System Strategies. USA: Prentice Hill.

Budiyanti, H. (2015). Analisis Kebutuhan Pelatihan Petugas Rekam Medis Rumah Sakit Mata (Studi dilakukan di RS Mata Undaan Surabaya). Skripsi. Surabaya: Universitas Airlangga.

Hananto, S., \& Kriswiharsi Kun, S. (2013). TINJAUAN PENGGUNAAN SISTEM PENJAJARAN DRM DENGAN METODE SNF DI FILLING RS MUHAMMADIYAH KENDAL.https://www.google.co.id/?gws_rd=c $r$,ssl\&ei=dyfpVeqzHMe50gThu7SYCW\#q=TIN JAUAN\%09PENGGUNAAN+SISTEM+PENJ AJARAN\%09DRM+DENGAN+METODE+SN $F+D I+F I L L I N G \% 09 R S+M U H A M M A D I Y A H+K$ ENDAL. (Sitasi 15 Agustus 2015)

Lutfi. (2008). Prosedur Analisis Kebutuhan Diklat. Jurnal Diklat Kepegawaian .

Notoadmojo. (2003). Pengembangan Sumber Daya Manusia. Jakarta: Rineke Cipta.

Robbins. (2007). Perilaku Organisasi. Jakarta: Salemba Empat.

RSMU. (2013). Analisis Komplain. Surabaya: Rumah Sakit Mata Undaan Surabaya.

Setyowati, E. (2007). Pengembangan SDM Berbasis Kompetensi: Solusi Untuk Meningkatkan Kinerja Organisasi,. Hasil Penelitian. https://www.google.co.id/?gws_rd=cr,ssl\&ei= XyPpVYDnMafLmAWnwlOYAg\#q=Pengemb angan+SDM+Berbasis+Kompetensi:+Solusi+ Untuk+Meningkatkan+Kinerja+Organisasi (Sitasi 15 Agustus 2015) .

Simamora. (2006). Manajemen Sumber Daya Manusia Edisi III. Yogyakarta: Sekolah Tinggi IImu Ekonomi YKPN

Supriyanto, S., \& Wulandari, R. (2010). Manajemen Mutu. Surabaya: Universitas Airlangga.

Tamba, R. F. (2009). Analisis Kebutuhan Pelatihan Perawat Pelaksana melalui Training Need Assesment di RS.Onkologi Surabaya. Skripsi. Surabaya: Universitas Airlangga. 
Veithzal, R. (2004). Manajemen Sumber Daya Manusia Untuk Perusahaan. Jakarta: PT. Raja Grafindo.
Wulandari, R. (2005). Penilaian Kebutuhan Pelatihan : Tantangan dan Solusi. Jurnal Siasat Bisnis. Edisi Tahun I Volume 5, 75-86 